Кай Летіцій. Твоя дочка й найбільшої достойна (с. 27) і прислівників: Фортунат. Авжеж, найкраще так, нехай єпископ (с. 71); Прісцілла. По чім же признають найбільще нас? (с. 46); Прісцілла. Таж єпископ найдальше мешкає (с. 53); Аецій Панса. Найкраще так, побачити на очі, тоді ніяким брехням не повіриш ( (с. 21); Сервілія. Там був один... старий вже дідуган, так той найбільие вабив (с.37).

Як показують приклади, в драмі Лесі Українки «Руфін і Прісцілла» функціонує багато словотворчих та формотворчих часток. Словотворчі частки беруть участь в утворенні певних груп слів, формотворчі частки допомагають творити наказовий, умовний спосіб дієслова, найвищий ступінь порівняння прикметників та прислівників. Дослідження типів часток можна продовжити, аналізуючи інші драматичні твори письменниці.

\title{
Література:
}

1. Плющ М.Я. Граматика української мови. Морфеміка. Словотвір. Морфологія: підручник. К. : Видавничий Дім «Слово», 2010. 2-е видання, доповнене. $328 \mathrm{c}$.

2. Сучасна українська літературна мова. Морфологія / за заг. ред. І.К. Білодіда. К. : Наук. думка, 1969. 583 с.

DOI https://doi.org/10.30525/978-9934-26-073-5-1-4

\section{ГЛЮТОНІЙНІ ПАРЕМІЇ ЯК ЗГУСТКИ ЛІНГВОКУЛЬТУРНОЇ ІНФОРМАЦІЇ НАЦІОНАЛЬНОЇ СПІЛЬНОТИ}

\author{
Колоїз Ж. В. \\ доктор філологічних наук, професор, \\ завідувач кафедри украӥнської мови \\ Криворізького державного педагогічного університету \\ Масляєва I. В. \\ здобувач вищої освіти PhD 035 Філологія \\ Криворізького державного педагогічного університету \\ м. Кривий Ріг, Дніпропетровська область, Украӥна
}

Питання про те, як відбувається вербалізація культури, не нове. Мовознавці різних часів і народів у той чи той спосіб досліджують специфіку втілення в мовні форми елементів матеріальної й духовної 
культури, які мають виразний національний компонент, з'ясовують вплив етнокультурних чинників на функціонування мови, роблять спробу реконструювати національно-мовні картини світу, національний світогляд, національні цінності i т. ін. Наявні як вітчизняні, так i зарубіжні наукові доробки являють собою своєрідну лінгвістичну панораму, де, немов у кінострічці, з'являються певні інформаційно навантажені кадри про відповідні лінгвоодиниці, що вирізняються національно-культурним забарвленням.

Ніколи й ні в кого не виникало жодних сумнівів стосовно уналежнення до таких мовних знаків одиниць паремійного корпусу, диференційованого на власне паремійний та афористичний різновиди. I це цілком закономірно. Адже, як відомо, насамперед власне паремії, або так зване «народне мудрослів'я», $\epsilon$ не лише відповідними моральноціннісними орієнтирами того чи того етносу, але й його історичною пам'яттю, так би мовити, згустками лінгвокультурної інформації. Лаконічні і влучні, вони акумулюють і транслюють життєвий досвід національної спільноти, іï світоглядні позиції, вироблені суспільною практикою, матеріальну й духовну культуру, народний побут, повір'я й обряди і т. ін.

Невід'ємною складовою повсякденного національного буття, однією 3 основних потреб людського життя, безумовно, є культура харчування (Млин меле водою, а чоловік живе їдою), представлена як предметними, так і мовними знаками, останні з яких, актуалізуючи концепт «їжа», формують харчову, або глютонійну, картину світу, являють собою відповідний лінгвокод, що передбачає систему знаків, які стали носіями культурних смислів. Харчовий, або глютонійний, лінгвокод оперує вербальними знаками, у структурі яких зашифровані наші уявлення про світ, грунтовані на харчових образах, що отримали номінацію. Ці та інші аспекти вже неодноразово ставали об'єктом зацікавлення науковців (Н. Андрейчук， Л. Борис， Д. Гудков， М. Ковшова， В. Кононенко, В. Красних, Л. Савченко, О. Селіванова, В. Телія та ін.). Проте вивчення вербальних знаків у контексті взаємозв'язку народної культури лише набирає обертів. Наразі на порядку денному витлумачення поняття «Глютонійна паремія», його осмислення, зокрема й через кваліфікацію згустків лінгвокультурної інформації.

Відштовхуючись від традиційних потрактувань паремії загалом i власне паремії зокрема [2], вважаємо за доцільне дефініціювати поняття «Глютонійна паремія» як репродуктивний мовний знак, у якому зашифрована інформація про культуру національного харчування, «харчові» традиції, звичаї, погляди, досвід, смаки, норми поведінки i 
т. ін., які склалися історично й передаються від покоління до покоління: Ми люди прості: хліба скибку, сяку-таку рибку, сала шматочок, солі дрібочок та горілочки чарчину, заморюся, чхну та й знову почну; Перше м'ясо - свинина, перша риба - линина; Риба - вода, ягода - трава, а хліб - усьому голова; Що до чого, а борщ до хліба; Книш - не пиріг; Редьчин хвіст на великий піст; Гречана каша хвалилася, ніби вона з коров'ячим маслом родилася; 3 попелу галушки не вдаються до юшки; 3 пшона й дурень каші наварить; Наш піддячий любить борщ гарячий, а як голодний, їсть і холодний; Де сало шкварчить, там людей кишить i т. ін. Проілюстровані паремії відбивають специфіку національного світосприйняття, етносвітогляду, а система образних і символічних смислів, пов'язаних із традиціями харчування, транслює «прислівні етнокадри», що зазвичай $\epsilon$ результатами компресії, ущільнення інформації з окремих епізодів людського життя.

Як і будь-які пареміологічні одиниці, глютонійні паремії $\epsilon$ еталонними знаками, вирізняються відносною усталеністю й відтворюваністю, афористичністю, переосмисленим чи буквальним узагальненим значенням, актуалізуючи відповідні глютонійні найменування, апелюють до так званих національних продуктів чи страв, їх місця і ролі в національній кухні і споконвічних технологій їх приготування. Такі знаки $є$ не лише фрагментами культури, але й одиницями мовної свідомості, сприяють формуванню поняття «концепт» у контексті концептуального підходу, що поєднує лінгвістичний і культурологічний аспекти, розглядаючи знак - слово - поняття як одиницю мови. Їх варто досліджувати i 3 позицій етнолінгвістики крізь призму ментального способу мислення, з урахуванням напрацювань міфології, етнографії, фольклору, народного мистецтва і т. ін.

Глютонійні паремії, відображаючи харчову культуру народу, не тільки називають реалії об'єктивної дійсності, а й маніфестують ставлення до них, засвідчують ціннісні орієнтири народу. Так, скажімо, хліб - це символ достатку, добробуту і навіть життя, йому поклонялися так само, як і сонцю (пор.: віддавна домашній хліб випікають у формі сонця й називають святим), уважали головною їжею (Хліб - над усією їжею пан), без якої трапеза ставала неповноцінною, не відповідала стандартним вимогам (Не буде хліба, не буде й обіда; Без хліба половина обіда). Його основна, центральна, першорядна роль репрезентовано за допомогою різних стилістичних прийомів на зразок персоніфікації, або уособлення (Хліб - батько, вода -мати; Хліб за шлунком не ганяється, а шлунок за хлібом), заперечного порівняння (Бублик - не хліб; Риба - не хліб, ситий нею не будеш; Не кожний день Великдень, а хліб - не паска). 
Примітним є те, що глютонійні паремії з компонентом хліб є лише позитивно оцінними: про хліб погано не кажуть, якщо навіть із ним щось не так (Хліб глевкий - на зуби легкий; пор.: глевкий - «схожий на мокру глину; недопечений»), ситуацію обіграють у напрямку користі, вигоди, схвальних результатів. А загальновідома паремія Хліб та вода - то козацька їда побутує й у варіантній формі Хліб та вода - то спасенна їа, наштовхує на думку, що саме така модифікація могла відбутися в часи лихоліття, зокрема й голодоморів. Пор.: спасенна - «та, яка приносить рятунок, рятує або сприяє врятуванню від чого-небудь».

У межах паремійного корпусу актуалізуються й інші лексеми на позначення хлібних виробів, як-от: Паляниия - хлібові сестриия; Галушка та лемішка - хлібу перемішка (перемішка - «переміна»); Житній хліб - пирогів дід тощо. У давнину палянищею зазвичай називали хлібину, виготовлену з пшеничного борошна, певним чином замішаного. Згодом лексема набуває кількісної семантики, починає супроводжувати слово хліб, а словосполучення паляниця хліба отримує значення «хлібина, тобто один виріб із борошна певної форми; буханець». Галушка («різаний або рваний шматочок прісного тіста, зварений на воді або на молоці») чи лемішка («страва 3 густо звареного борошна, звичайно гречаного»), як і хліб, виготовлені з борошна, а тому можуть вживатися й без хліба, на відміну від деяких інших продуктів (пор.: Дурне сало без хліба; Рибка без хліба - бридка). У паремії Добрий хліб, коли нема калача лексема хліб супроводжувана атрибутивним поширювачем добрий, актуалізує значення «який має позитивні якості або властивості, що відповідають поставленим вимогам, задовольняють ïx; повністю забезпечує потребу в чому-небудь» (пор.: калач «білий хліб особливої форми, випечений із крученого й переплетеного тіста»). Концептуальний аналіз таких одиниць $є$ «ключем» до свідомості лінгвоспільноти, спродукованої нею концептуальної картини світу, уможливлює декодування інформації, яка зберігається в глютонійних пареміях і є результатом мовленнєво-мисленнєвої діяльності, пов'язаної зі сферою харчування у широкому потрактуванні. Адже глютонійні концепти, окрім мовного, передбачають і культурний компонент, грунтований на суспільно-історичному досвіді етносу загалом і кожної людини зокрема.

Саме від наявного досвіду залежить здатність декодувати глютонійні паремії як знаки ситуацій, що являють собою згустки лінгвокультурної інформації. Під час їх сприйняття відбувається декодування концептуальних структур, залучених до продукування. Наприклад, паремія на зразок Кутя на покуття, а узвар - на базар - це, з одного 
боку, семіотичний спосіб репрезентації ритуальних страв різдвяного обряду, згідно з яким їх готують у Святвечір та Щедрий вечір і ставлять на покуті (покутті) - найсвятішому і найпочеснішому місці в селянській хаті, форма функціонування та зберігання елементів культури, 3 іншого, - це мовний засіб пізнання, що сприяє розширенню смисло_ вих горизонтів людської культури. За лексемою кутя закріпилося традиційне значення «обрядова каша з ячмінних або пшеничних зерен, уживана 3 солодкою підливою напередодні Різдва чи Водохреща»; диференційні семи спричинили модифікацію поняття, його конкретизацію із залученням атрибутивних поширювачів (Багата / Щедра / Голодна). Подекуди спостерігаємо й видозмінену семантику (кутя - «відварені у воді зерна пшениці чи ячменю з медом; традиційна ритуальна страва новорічно-різдвяного циклу» (пор.: Передати куті меду), і доповнену диференціацію (Чорна кутя). Глютонійні паремії характеризуються розмаїттям асоціацій, пов'язаних із особливостями сприйняття об'єктивної дійсності носіями культури, їх національна специфіка зумовлена як інтралінгвальними, так і екстралінгвальними чинниками.

Насамкінець зауважимо: глютонійні паремії є важливим фрагментом концептуальної картини світу, що репрезентує широку палітру знаків із культурно маркованим змістом. Вербалізатори концептів національної харчової культури потребують скрупульознішого вивчення із залученням здобутків різних наукових царин, що дасть змогу підібрати потрібні «ключі» для безперешкодного доступу до національно значущої інформації.

\section{Література:}

1. Жайворонок В. Знаки української етнокультури. Словникдовідник. Київ, 2006. 704 с.

2. Українська пареміологія : навч. посіб. / Ж. В. Колоїз, Н. М. Малюга, Н. М. Шарманова. Кривий Ріг : ДВНЗ «КНУ», 2014. 349 с. 